\title{
KOMITET DLA SPRAW KRAJU. ZARYS DZIAŁALNOŚCI ADAMA CIOŁKOSZA W LATACH 1940-1942
}

\section{Lilla Barbara PASZKIEWICZ (Legnica)}

Klęska wrześniowa 1939 roku, internowanie władz polskich w Rumunii ${ }^{1}$, a także powstanie nowego rządu na uchodźstwie (30 września) spowodowały, iż sprawą priorytetową stało się dla niego (tj. rządu) utrzymanie stałej łączności z okupowanym kra$j^{j e m^{2}}$. Już 2 października premier Władysław Sikorski powierzył ministrowi Adamowi Ładosiowi „zadanie nawiązania poufnej komunikacji z krajem w dziedzinie politycznej”’3. Po przybyciu do Francji gen. Kazimierza Sosnkowskiego (11 października 1939 roku) Prezydent mianował go swoim następcą, a premier powierzył mu, jako ministrowi bez teki, misję zorganizowania i utrzymania łączności z krajem oraz współpracy z wojskowym podziemiem ${ }^{4}$. Działania obu ministrów zostały wykorzystane do urzeczywistnienia koncepcji „objęcia kraju jakąś formą opieki i przywództwa [...]”.

\footnotetext{
${ }^{1}$ W Rumunii internowany został prezydent RP Ignacy Mościcki, premier Felicjan Sławoj-Składkowski i Wódz Naczelny Edward Rydz-Śmigły. Prezydent korzystając ze swych konstytucyjnych uprawnień (art. 13 Konstytucji Kwietniowej z 1935 r.) mianował swoim następcą Władysława Raczkiewicza, który powołał na stanowisko premiera rządu na uchodźstwie (we Francji) gen. W. Sikorskiego. W skład jego gabinetu weszli przedstawiciele opozycji antysanacyjnej oraz politycy sanacji.

${ }^{2} \mathrm{Na}$ temat sytuacji politycznej spowodowanej skutkami klęski wrześniowej zob. szerzej np.: M. Hułas, Goście czy intruzi? Rząd polski na uchodźstwie wrzesień 1939 - lipiec 1943, Warszawa 1996; E. Duraczyński, Polska 1939-1945. Dzieje polityczne, Warszawa 1999; tenże, Rzqd polski na uchodźstwie 1939-1945, Warszawa 1993; Władze RP na obczyźnie podczas II wojny światowej, pod red. Z. Błażyńskiego, Londyn 1994.

${ }^{3}$ Protokoty z posiedzeń Rady Ministrów Rzeczypospolitej Polskiej, t. I: październik 1939 czerwiec 1940, oprac. W. Rojek, A. Suchcitz, Kraków 1994, s. 4-7.

${ }^{4}$ Jeszcze w czasie kampanii wrześniowej powstała tajna organizacja wojskowa - Służba Zwycięstwu Polski. Na temat okoliczności powstania SZP pisze m.in. G. Górski, Polskie Pań-
} 
W związku z pracami przygotowawczymi nad kształtem konspiracji w kraju i potrzebą objęcia ruchu oporu nadzorem, Rada Ministrów 8 listopada 1939 roku podjęła decyzję o powołaniu Komitetu Ministrów dla Spraw Kraju (KMSK). Jego przewodniczącym został gen. K. Sosnkowski, a zastępcą gen. Marian Kukiel. W składzie Komitetu znaleźli się także ministrowie: Adam Ładoś (SL), Marian Seyda (SN) i Jan Stańczyk (PPS) ${ }^{6}$. Pierwszy skład KMSK przetrwał do stycznia 1940 roku, kiedy to premier wprowadził do Komitetu prof. Stanisława Kota oraz przedstawicieli Rady Narodowej ${ }^{7}$ : Tadeusza Bieleckiego i Stanisława Mikołajczyka (zastąpili A. Ładosia i M. Seydę). Zmieniono również nazwę KMSK na Komitet dla Spraw Kraju (KSK).

Zgodnie z założeniami KSK miał kierować sprawami cywilnymi z zakresu opieki społecznej, informacji i propagandy oraz łączności z krajem. Do jego obowiązków należało także „czuwanie nad wszystkimi sprawami związanymi z krajem i tajnymi wysiłkami narodu, zmierzającymi do wyzwolenia Rzeczypospolitej z okupacji wroga; wypracowane przez ten komitet wskazania polityczne dla kraju miały być wydawane przez szefa rządu bezpośrednio lub też w jego imieniu, ale po uprzedniej z jego strony aprobacie" ". Sprawami wojskowymi miała kierować Komenda Główna ZWZ z siedzibą w Paryżu, a następnie w Angers ${ }^{9} .13$ listopada 1939 roku jej komendantem Głównym został gen. K. Sosnkowski. Podlegał on Naczelnemu Wodzowi - gen W. Sikorskiemu $^{10}$.

W celu usprawnienia łączności z krajem w początkowej fazie funkcjonowania KSK podjęto decyzję oparcia jej na mężach zaufania rządu, dzięki którym docierać miały z okupowanych ziem polskich informacje na temat warunków życia Polaków

stwo Podziemne 1939-1945, Toruń 1998, s. 49-56; zob. też: J. Karasiówna, Pierwsze pótrocze armii podziemnej (S.Z.P.-Z.W.Z.), Niepodległość 1948 t. 1, s. 267-277.

${ }^{5}$ M. Dymarski, Stosunki wewnętrzne wśród polskiego wychodźstwa politycznego i wojskowego we Francji i w Wielkiej Brytanii 1939-1945, Wrocław 1999, s. 48.

${ }^{6}$ Skład KMSK budził w kręgu osób wtajemniczonych w kraju poważne zastrzeżenia. Uważano bowiem, iż tylko gen. K. Sosnkowski i gen. M. Kukiel mają doświadczenie konspiracyjne z lat 1905-1918, a pozostali ministrowie nie mają żadnego przygotowania do koordynowania działań konspiracyjnych; zob.: S. Korboński, Polskie Państwo Podziemne, Paryż 1975, s. 30.

${ }^{7}$ Rada Narodowa RP została powołana 9 grudnia 1939 r. (w miejsce rozwiązanego 2 października 1939 r. parlamentu II RP). Jako jedynie substytut parlamentu pełniła rolę organu doradczego prezydenta i premiera na uchodźstwie. Na czele Rady Narodowej stał Ignacy Paderewski.

${ }^{8}$ W. Pobóg-Malinowski, Najnowsza historia polityczna Polski 1939-1945, t. 3, Kraków 2004, s. 123.

${ }^{9}$ ZWZ został powołany na miejsce Służby Zwycięstwu Polski (powstałej 27 września 1939 r.). Jej dowódcą był gen. Michał Karaszewicz-Tokarzewski, który mimo uznania zwierzchnictwa Rządu Polskiego na uchodźstwie, wykazał nielojalność wobec Naczelnego Wodza, przesyłając raport do gen. W. Sikorskiego przez marszałka E. Rydza-Śmigłego. Fakt ten zadecydował o rozwiązaniu SZP i powołaniu ZWZ w myśl zasad opracowanych przez Sikorskiego. Dowódcą ZWZ został początkowo K. Sosnkowski, a następnie Stefan Rowecki (okupacja niemiecka) i M. Karaszewicz-Tokarzewski (okupacja sowiecka). Zgodnie z instrukcją Naczelnego Wodza oraz KMSK, ZWZ miało być organizacją jedynie wojskową o charakterze ogólnonarodowym i ponadpartyjnym, której głównym celem miała być walka z okupantami oraz przygotowanie powstania zbrojnego na tyłach ich armii z chwilą wkroczenia regularnych wojsk polskich. Twórcy instrukcji nie przewidzieli, iż losy wojny potoczą się zupełnie innym torem i jako pierwsza na ziemie polskie wkroczy Armia Czerwona; szerzej zob.: S. Korboński, Polskie Państwo Podziemne, s. 3; L. M. Bartelski, AK. Podziemna armia 27 IX 1939-30 VI 1943, t.1, Warszawa 1990.

${ }^{10}$ Gen. K. Sosnkowski w początkowym okresie łączył funkcje dowódcy zbrojnego podziemia w Polsce z obowiązkami przewodniczącego KMSK. 
oraz potrzebach tworzącego się życia podziemnego zarówno w sferze politycznej, jak i wojskowej ${ }^{11}$.

Według Mirosława Dymarskiego konieczność organizacji łączności z krajem „stała się polem nie współdziałania, lecz rywalizacji”. Wynikało to faktu, iż emigracyjni politycy liczyli na rychłe zakończenie wojny i powrót do kraju oraz przejęcie władzy w nowych warunkach ${ }^{12}$. Zaznaczyła się wówczas rywalizacja między rządem Sikorskiego a politykami sanacji. Ekipa rządowa starała się wpływać na nastroje rodaków w okupowanym kraju i zdyskredytować przedwojennych polityków w oczach opinii publicznej, obarczając ich winą za klęskę wrześniową. Porozumienia nie ułatwiał fakt, iż „rząd Sikorskiego „traktował zdobytą władzę jako należne jej prawo, nagrodę, zdobycz [...]" i starał się wszelkimi możliwymi sposobami i środkami bronić swojej pozycji uważając, że , jest to słuszne dla narodu i kraju" "13. Nie było to łatwe przedsięwzięcie biorąc pod uwagę fakt, iż w rządzie W. Sikorskiego nie znaleźli się politycy o wystarczającym autorytecie, zdolni do podejmowania trudnych wyzwań w okresie wojny $\mathrm{i}$ budowy jedności narodowej ${ }^{14}$. Prowadzili oni działania zmierzające do wyeliminowania z życia politycznego i publicznego osób, które sprawowały rządy w Polsce po 1926 roku.

Do najbardziej zaciekłych i nieprzejednanych wrogów sanacji należał bliski i zaufany współpracownik premiera W. Sikorskiego - prof. S. Kot ${ }^{15}$. To w dużej mierze pod jego wpływem premier tracił zaufanie do polityków sanacyjnych i potępiał ich przedwojenne działania. Jednocześnie gen. W. Sikorski nawoływał do współpracy i „odłożenia na bok wszelkich sporów”, deklarując usuwanie ludzi, którzy nie chcą lub nie potrafią podjąć się harmonijnej współpracy dla dobra Polski ${ }^{16}$. Wobec takiej strategii premiera i jego współpracowników możliwości porozumienia z politykami sanacji były bardzo ograniczone, a prowadzona rywalizacja nie sprzyjała wzmocnieniu pozycji Polski zarówno w polityce wewnętrznej, jak i na arenie międzynarodowej.

Mimo skomplikowanej sytuacji politycznej na emigracji, która nie sprzyjała konstruktywnym działaniom, gen K. Sosnkowski podjął się wypracowania wytycznych dotyczących organizacji cywilnej i wojskowej w okupowanym kraju. Zaproponował, aby w ramach KSK funkcjonowały dwa działy: ogólny i wojskowy. Pierwszy z nich miał zajmować się działalnością cywilną: opiekuńczą, informacyjną i propagandową, a także łącznością z krajem. Dział drugi miał obejmować czynności związane z utworzeniem na terenie kraju tajnej organizacji wojskowej ${ }^{17}$. W oparciu m.in. o te koncepcje

\footnotetext{
${ }^{11}$ M. Dymarski, Stosunki wewnętrzne..., s. 49.

12 Tamże.

${ }^{13}$ Tamże, s. 50.
}

${ }^{14}$ Premier W. Sikorski obawiał się wzmocnienia wpływów sanacyjnych zarówno na emigracji, jak i w kraju. Sytuacja ta nasiliła się zwłaszcza po utworzeniu w Rumunii Organizacji Pracy na Kraj i podjęciu przez byłego premiera F. Sławoja-Składkowskiego działań zmierzających do wykorzystania we Francji dawnych urzędników państwowych z obozu sanacyjnego; zob.: F. Sławoj-Składkowski, Nie ostatnie stowo oskarżonego, Londyn 1964, s. 352-353; por.: T. Dubicki, S. J. Rostworowski, Sanatorzy kontra sikorszczycy, czyli walka o władze na uchodźstwie w Rumunii 1939-1940, Warszawa 1993.

${ }^{15}$ Zob.: W. Pobóg-Malinowski, Najnowsza historia..., s. 89.

16 Szerzej zob.: Archiwum Zakładu Historii Ruchu Ludowego w Warszawie (dalej: AZHRL), Kolekcja S. Kota, sygn. 174.

17 Treść zasad organizacyjnych pracy w kraju, [w:] Protokoty z posiedzeń Rady Ministrów..., s. 71-77. 
powstały na ziemiach okupowanych struktury państwa podziemnego ${ }^{18}$, które ściśle współpracowało z legalnymi władzami polskimi na uchodźstwie.

KSK zajmował się przede wszystkim losami ludności na terenach zajętych przez okupantów. Jednak premier W. Sikorski oraz jego rząd dość często wykorzystywali komitet do rozpatrywania i opiniowania szeregu zagadnień politycznych, które nie miały bezpośredniego związku ze sprawami kraju ${ }^{19}$.

Na początku 1940 roku w związku z napływem do Francji kilku polityków, którzy po klęsce wrześniowej opuścili ziemie polskie i różnymi drogami starali się dotrzeć do władz polskich we Francji, rozszerzył się skład zarówno Rady Narodowej, jak i KSK.

Wśród przybyłych osób znalazł się również jeden z czołowych działaczy przedwojennego PPS - Adam Ciołkosz ${ }^{20}$. Należał on do polityków, którzy w swoim dorobku mieli udział w walkach o niepodległość Polski w okresie I wojny światowej oraz w czasie kształtowania się granic państwa polskiego. Brał udział zarówno w walkach o Lwów, jak i w wojnie polsko-bolszewickiej oraz w plebiscycie na Warmii i Mazurach. Uczestniczył także w III Powstaniu Śląskim.

Swoją działalność polityczną w PPS Adam Ciołkosz rozpoczął podczas studiów w Krakowie, gdzie przewodniczył Sekcji Akademickiej PPS oraz był aktywnym członkiem Związku Niezależnej Młodzieży Socjalistycznej. Oprócz działalności politycznej zajmował się także pracą redakcyjną. W 1924 roku został redaktorem socjalistycznego dziennika „Naprzód”. W wieku 27 lat wybrano go z listy PPS posłem w wyborach parlamentarnych $(1928 \text { roku })^{21}$. Znalazł się w grupie przeciwników sanacji. Dwa lata później ponownie zdobył mandat z unieważnionej później listy Centrolewu. Wkrótce został aresztowany i oskarżony o działalność antysanacyjną uwięziony w twierdzy brzeskiej. W procesie brzeskim (1932 roku) został skazany na trzy lata więzienia i dziesięć lat pozbawienia praw obywatelskich ${ }^{22}$.

Od 1931 roku aż do wybuchu II wojny światowej A. Ciołkosz należał do kierownictwa PPS jako członek Rady Naczelnej i Centralnego Komitetu Wykonawczego PPS. W latach 1936-1939 działał bardzo aktywnie (jako przewodniczący) w Okręgowym Komitecie Robotniczym PPS Ziemi Krakowskiej. Po wybuchu wojny, w obawie przed aresztowaniem przez gestapo, udał się do Łucka, a następnie dotarł do Lwowa, gdzie

\footnotetext{
${ }^{18} \mathrm{Na}$ temat koncepcji podziemia cywilnego i wojskowego oraz struktury Polskiego Państwa Podziemnego zob.: G. Górski, Polskie Państwo Podziemne..., s. 70-100; szerzej zob.: S. Korboński, Polskie Państwo Podziemne; S. Dołęga-Modrzewski, Polskie Państwo Podziemne, Londyn 1959; W. Bartoszewski, Polskie Państwo Podziemne, Poznań 1980; S. Salmonowicz, Polskie Państwo Podziemne. Z dziejów walki cywilnej 1939-1945, Warszawa 1994; T. Wyrwa, Bezdroża dziejów Polski. Kraj i emigracja po 1 września 1939 r., Lublin 1998.

${ }^{19}$ Protokoty Posiedzeń Komitetu dla Spraw Kraju, cz. 1: 1939-1941, oprac. i red. W. Grabowski, Warszawa 2008, s. 27.

${ }^{20}$ Adam Ciołkosz urodził się w 1901 r. w rodzinie o patriotycznych tradycjach. Jego ojciec Kacper Ciołkosz - jako nauczyciel gimnazjalny stanowił wzór działalności społecznej w Tarnowie, gdzie mieszkał i pracował wraz z żoną Marią i dwoma synami: Adamem i Zbysławem. Adam Ciołkosz od najmłodszych lat angażował się w powstanie i rozwój ruchu skautingowego w Tarnowie. Pod koniec I wojny światowej, jako szesnastoletni młodzieniec pełnił funkcję komendanta „Dzielnicy Tarnowskiej” i uczestniczył wraz z oddziałami POW w rozbrajaniu Austriaków (30/31 X 1918 r.) w Tarnowie; szerzej zob.: M. Żychowska, Harcerstwo tarnowskie 1910-1939, Tarnów 1992.

${ }^{21}$ Szerzej na temat działalności parlamentarnej Adama Ciołkosza zob.: A. Friszke, Adama Ciołkosza droga do sejmu, [w:] Kuchnia wtadzy. Księga pamiątkowa z okazji 70-tej rocznicy urodzin A. Garlickiego, pod red. W. Borodzieja, J. Kochanowskiego, Warszawa 2005, s. 96-119.

${ }^{22}$ Szerzej zob.: A. Ciołkosz, Sprawa brzeska (Polemiki i listy), Zeszyty Historyczne 1966 z. 9, s. 218-227.
} 
łącznik Kazimierza Pużaka (sekretarza CKW PPS) przekazał A. Ciołkoszowi polecenie jak najszybszego dotarcia do Francji, aby we władzach polskich reprezentować PPS ${ }^{23}$. Przyjazd do Paryża opóźnił pobyt A. Ciołkosza w Rumunii i dopiero w lutym 1940 roku udało mu się przedostać do Francji, gdzie dołączyła do niego żona wraz z synem.

Od samego początku włączył się aktywnie w działania władz emigracyjnych. 4 marca 1940 roku Prezydent Rzeczypospolitej mianował A. Ciołkosza członkiem Rady Narodowej ${ }^{24}$. Został także wybrany sekretarzem Komitetu Zagranicznego PPS. Co prawda oficjalnie premier W. Sikorski powołał go na członka Komitetu dla Spraw Kraju dopiero 28 stycznia 1941 roku (w miejsce J. Stańczyka) ${ }^{25}$, ale A. Ciołkosz jako gość uczestniczył w obradach KSK już od 15 kwietnia 1940 roku..

24 kwietnia na posiedzeniu informacyjnym Komitetu omawiano dość szeroko sprawy okupowanej Wileńszczyzny. Generał K. Sosnkowski chciał uzyskać informacje na temat sytuacji oraz potrzeb Polaków na tym obszarze w sferze politycznej, gospodarczej i kulturalnej, które umożliwiłyby utrzymanie polskości na Wileńszczyźnie do chwili uzyskania wolności ${ }^{26}$. Przewodniczący KSK chciał określić wielkość środków niezbędnych na ten cel oraz poznać formy udzielenia pomocy finansowej. Interesowały go także możliwości utworzenia na Wileńszczyźnie organizacji wojskowych ${ }^{27}$.

${ }^{23}$ Tenże, Kartki z przeszłości, Zeszyty Historyczne 1980 z. 51, s. 12; pod koniec 1939 r. we Francji PPS reprezentowało czterech polityków: A. Pragier, J. Stańczyk, T. Tomaszewski i H. Lieberman. Główni przywódcy: M. Niedziałkowski, K. Pużak, Z. Zaremba, T. Arciszewski, Z. Żuławski pozostali w kraju; szerzej zob.: R. Stefanowski, PPS na emigracji 1939-1965, Kraków 1996; W. Suleja, PPS 1892-1948, Warszawa 1988.

${ }^{24}$ Instytut i Muzeum im. gen. Sikorskiego w Londynie (dalej: AIMPS), Akt mianowania A. Ciołkosza, sygn. 133/382.

${ }^{25}$ AIMPS, zespół Prezydium Rady Ministrów, Nominacja A. Ciołkosza na członka KSK, sygn. $45 \mathrm{D}, \mathrm{k} .2$.

${ }^{26}$ O losach Wileńszczyzny zadecydował układ sowiecko-niemiecki o granicy i przyjaźni podpisany w dniu 28 września 1939 r. W tajnym protokole zawarto informacje o tym, iż Litwa znajdzie się w sowieckiej strefie wpływów. Już od końca września we wszystkich trzech państwach bałtyckich organizowano sowieckie bazy wojskowe. Według niektórych historyków, okupowana od 17 września 1939 r. przez Sowietów, Wileńszczyzna została obiecana Litwinom w zamian za zgodę na stacjonowanie na Litwie wojsk sowieckich. Dopóki jednak to nie nastąpiło, na okupowanych terenach władzę sprawowało NKWD, dokonując masowych aresztowań, szczególnie wśród ludności polskiej, przede wszystkim działaczy państwowych i społecznych, lekarzy, prawników, urzędników. Przekazanie Wilna i Wileńszczyzny Litwie odbyło się w dniu 26 października 1939 r. Początkowy życzliwy stosunek Litwinów do Polaków uległ zdecydowanemu pogorszeniu po 28 października 1939 r. Litwini dążyli do wyeliminowania żywiołu polskiego, który był dla nich „,wrogiem numer 1”. Uważali bowiem, że wolna Litwa może istnieć tylko wówczas, kiedy Polski nie ma; zob.: Protokoty Posiedzeń Komitetu dla Spraw Kraju..., s. 247; W. Pobóg-Malinowski, Najnowsza historia polityczna Polki, s. 102-106. 3 sierpnia 1940 r. nastąpiło ponowne zajęcie Litwy przez ZSRR i stopniowe przekształcenie jej w republikę sowiecką. Pociągnęło to za sobą nie tylko zmiany prawno-ustrojowe, ale także liczne represje, przede wszystkim w stosunku do przedstawicieli litewskich władz państwowych i samorządowych. W następnej kolejności przystąpiono do oczyszczania terytorium Litwy z tzw. elementów antysowieckich. Zaliczano do nich przede wszystkim inteligencję (polską oraz litewską, która nie podjęła współpracy z Sowietami): naukowców, nauczycieli, oficerów, urzędników ministerialnych, arystokratów, kupców, ziemian, właścicieli hoteli i restauracji; szerzej zob.: J. Siedlecki, Losy Polaków w ZSRR w latach 1939-1986, Londyn 1987; A. Głowacki, Sowieci wobec Polaków na ziemiach wschodnich II Rzeczypospolitej 1939-1941, Łódź 1998.

27 A. Pachowicz, Decyzje Komitetu dla Spraw Kraju w sprawie Wileńszczyzny (listopad 1939 - kwiecień 1940 r.), Dzieje Najnowsze 2005 nr 2, s. 47-50. 
Z krytyką działań rządu polskiego w zakresie pomocy mieszkańcom Wileńszczyzny wystąpił Stanisław Mackiewicz — znawca stosunków wileńskich. Zakwestionował on udzielanie pomocy finansowej przez komitet W. Zagórskiego, który był „legalną ekspozyturą komunistyczną,"28. Co prawda, S. Mackiewicz uważał W. Zagórskiego za „,bardzo porządnego człowieka”, miał jednak zastrzeżenia do jego powiązań z komunistami. Uważał, iż pomocą dla ludności wileńskiej powinna się zajmować „firma polska"29.

W dyskusji nad sprawami pomocy dla Wileńszczyzny głos zabrał (jako gość) A. Ciołkosz, który stanął w obronie W. Zagórskiego podkreślając, że „mecenas Zagórski sprawie polskiej oddaje duże zasługi" i jego przeszłość nie powinna być przedmiotem tak ostrej krytyki, gdyż wiele osób pod wpływem bezpośredniego kontaktu i tragicznych doświadczeniach z Sowietami doszło do przekonania, iż „w komunizmie nie

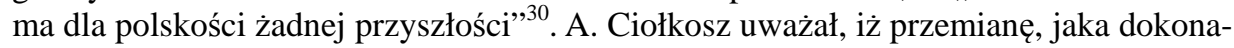
ła się w postawie W. Zagórskiego należy wykorzystać dla dobra narodu polskiego i z tego względu opowiadał się za nielikwidowaniem komitetu prowadzonego przez mecenasa $^{31}$.

Na zakończenie swojego wystąpienia A. Ciołkosz poruszył sprawę stosunków żydowskich na terenie Wileńszczyzny. Podkreślił, iż, co prawda część Żydów przeszła na stronę sowiecką, ale byli również tacy, którzy się całkowicie od nich odwrócili i prowadzą antysowiecką agitację. Do tej grupy należą członkowie Bundu ${ }^{32}$, którzy „są bezwzględnie lojalni w stosunku do Polaków"33.

Obrady KSK zostały przerwane na skutek wydarzeń wojennych i kapitulacji Francji, w wyniku której władze polskie przeniosły się do Wielkiej Brytanii. Pod koniec czerwca do Londynu przedostał się także A. Ciołkosz wraz z rodziną.

Ze względu na ,przesilenie lipcowe” w rządzie polskim, związane z ewakuacją wojsk oraz instytucji polskich z Francji, wznowienie posiedzeń KSK nastąpiło 2 sierpnia 1940 roku. W tym okresie zaostrzył się konflikt między przewodniczącym Komitetu a otoczeniem premiera (głównie prof. S. Kot, S. Mikołajczyk, K. Popiel, J. Stańczyk). Sytuacja gen. K. Sosnkowskiego od początku pobytu na emigracji była niejasna i budziła kontrowersje, szczególnie wśród opozycji antysanacyjnej. Mimo swojej przeszłości generał cieszył się zaufaniem i uznaniem premiera. Z tego właśnie względu grupa przeciwników gen. Sosnkowskiego nie występowała z oficjalnym atakiem, ale podejmowała działania zmierzające do jego zdyskredytowania w oczach W. Sikorskiego. Szczególne zaangażowanie w tym zakresie wykazywał prof. Kot, który na posiedzeniu KSK w dniu 2 sierpnia rozpoczął frontalny atak na ZWZ, któremu zarzucano chęć podporządkowania sobie konspiracyjnych stronnictw w kraju ${ }^{34}$. Rząd obawiał się,

${ }^{28}$ Według S. Cata-Mackiewicza W. Zagórski należał do Związku Proletariatu Miast i Wsi (założony w 1922 r. przez działaczy Komunistycznej Partii Robotniczej Polski); zob.: Protokoty Posiedzeń Komitetu..., s. 252.

${ }^{29}$ Tamże.

${ }^{30}$ Tamże, s. 258. Na temat stosunku Sowietów do Polaków zob. szerzej: J. Siedlecki, Losy Polaków w ZSRR w latach 1939-1986, Londyn 1987; A. Głowacki, Sowieci wobec Polaków na ziemiach wschodnich II Rzeczypospolitej 1939-1941, Łódź 1998.

${ }^{31}$ Protokoty Posiedzeń Komitetu..., s. 258.

${ }^{32}$ Bund - lewicowo-socjalistyczna partia żydowska o charakterze antysyjonistycznym i antyreligijnym założona w Wilnie w 1897 roku.

${ }^{33}$ Tamże.

${ }^{34}$ Podobne zastrzeżenia miały stronnictwa konspiracyjne, które wysuwały zastrzeżenia, co do pośrednictwa organizacji wojskowej w łączności z rządem polskim. Zaufania nie budzili 
że w kraju powstanie niezależny centralny ośrodek kierowniczy — wojskowy i polityczny. Biorąc pod uwagę fakt, iż główne stronnictwa w kraju (mimo sanacyjnej przeszłości dowódców ZWZ) podjęły w imię wyższych racji współpracę z podziemną formacją wojskową, obawy rządu na uchodźstwie mogły okazać się słuszne. Dlatego podjął on działania zmierzające do podporządkowania sobie zarówno władz cywilnych, jak i politycznych bezpośrednio podległych rządowi polskiemu. W tym celu podzielono kraj na sześć obszarów wojskowych, z których każdy miał być dowodzony bezpośrednio z zagranicy. Zależność tę zmieniła decyzja podjęta 30 czerwca 1940 roku przez gen. K. Sosnkowskiego (uzgodniona z premierem) o powierzeniu gen. Roweckiemu funkcji Komendanta Głównego ZWZ (w miejsce Komendanta ZWZ przy rządzie) i powołanie Samodzielnego Wydziału Krajowego jako VI Oddziału Sztabu Głównego $^{35}$. W tym samym celu rząd na uchodźstwie lansował od początku koncepcję mianowania w kraju najpierw pięciu, a następnie trzech delegatów.

28 kwietnia 1940 roku KSK uchwalił szczegółowe wytyczne dotyczące współpracy delegatów rządu z przedstawicielami czterech głównych partii politycznych (SL, SN, PPS, SP) oraz ZWZ. 28 maja 1940 roku zgodnie z zasadami organizacyjnymi rząd miał powołać w kraju trzech głównych delegatów, po jednym na terenach włączonych do Rzeszy, Generalnej Guberni i na obszarze okupacji sowieckiej. Uchwałę w tej sprawie zatwierdziła Rada Ministrów w dniu 11 czerwca 1940 roku $^{36}$. Jej wykonanie uległo zwłoce na skutek klęski Francji i ewakuacji władz polskich do Wielkiej Brytanii.

Ze względu na wynik działań wojennych perspektywa szybkiej kontrofensywy aliantów i wyzwolenia Polski została odsunięta w czasie. Władze konspiracyjne stronnictw wraz z podziemną armią podjęły działania zmierzające do podjęcia dalszej walki z okupantami. W celu wzmocnienia sił struktury wojskowe ruchu oporu (ZWZ) zostały powiązane z cywilnymi (przedstawiciele SL, PPS, SN, a następnie także SP) w lipcu 1940 roku w Warszawie w ramach Zbiorowej Delegatury Rządu na Kraj ${ }^{37}$.

Wydarzenia w kraju znalazły swój oddźwięk podczas posiedzenia KSK w dniu 2 sierpnia 1940 roku. Generał K. Sosnkowski przypomniał, iż Komitet już w listopadzie 1939 roku podjął prace zmierzające do opracowania zasad organizacji pracy w kraju. 17 kwietnia 1940 roku został podjęta uchwała KSK w tej sprawie oraz zatwierdzono zadania i kompetencje delegatów rządu oraz ich współpracę z organizacja-

kurierzy wojskowi, którzy często dostarczali do kraju informacje od rządu w zniekształconej lub zafałszowanej formie. Czynniki polityczne w kraju obawiały się, iż ich działalność miała stanowić jedynie zaplecze dla działalności wojskowej, co w konsekwencji mogło doprowadzić do powstania nowej dyktatury wojskowej (na wzór przedwojennej). Relacji między rządem polskim a stronnictwami w kraju nie poprawiał także fakt wprowadzenia do władz emigracyjnych przedstawicieli sanacji (np. Adama Koca - działacza BBWR i założyciela Obozu Zjednoczenia Narodowego). Na temat zarzutów wobec organizacji wojskowej zob. korespondencję między premierem W. Sikorskim a gen. K. Sosnkowskim (3-4 IX 1940 r.); AZHRL, zespół S. Kota, k. $277-$ 293; Armia Krajowa w dokumentach 1939-1945, t. 1: 1939-1941, [kom. red. T. Pełczyński i in., do druku przygotował J. Żmigrodzki], Wrocław 1990, s. 324-325.

${ }^{35}$ Armia Krajowa $w$ dokumentach..., t. 1, s. 262-264.

${ }^{36} \mathrm{O}$ tej uchwale nie wiedział A. Ciołkosz oraz zasiadający w rządzie minister J. Stańczyk, ,którego niestety myśli w czasie ważnych debat rządowych i komisjach bujały zazwyczaj w obłokach marzeń o własnej, wielkiej i sławnej przyszłości”; A. Ciołkosz, Kartki z przeszłości, s. 17. Zdaniem S. Korbońskiego decyzje o powołaniu trzech delegatów rządu podległym bezpośrednio rządowi na uchodźstwie „wskazywały wyraźnie, że rząd nie rozumie, czy też nie chce rozumieć konieczności stworzonych przez okupację i kieruje się jedynie chęcią zapewnienia sobie niepodzielnej władzy, a nie interesu kraju"; zob.: S. Korboński, Polskie..., s. 39.

${ }^{37}$ E. Duraczyński, Kontrowersje i konflikty 1939-1941, Warszawa 1977, s. 266-267. 
mi politycznymi i wojskowymi w kraju. Generał K. Sosnkowski przypomniał również, iż do kraju został wysłany tymczasowy delegat rządu (płk. Jan Skorobohaty-Jakubowski, pseud. „Vogel”), który miał porozumieć się ze stronnictwami w sprawie ustalenia nazwisk kandydatów na delegatów, spośród których rząd miał dokonać wyboru i nominacji. 3 lipca 1940 roku w obecności tymczasowego delegata rządu uchwalono jednomyślną uchwałę przedstawicieli trzech stronnictw (SL, SN i PPS) oraz gen. S. Roweckiego i postanowiono powołać Delegaturę Rządu na Kraj złożoną na razie z czterech osób (trzech przedstawicieli stronnictw i komendanta ZWZ) z perspektywą rozszerzenia Delegatury o przedstawicieli kolejnych stronnictw ${ }^{38}$.

W meldunku do premiera W. Sikorskiego, dowódca ZWZ S. Rowecki wyjaśnił, iż „wobec zaistniałych wypadków” [klęska Francji i ewakuacja władz polskich do Wielkiej Brytanii - przyp. L.B.P.] oraz szoku, jaki wywołały one w kraju, powołanie Delegatury było jedynym słusznym rozwiązaniem, gdyż Delegatura Rządu na Kraj „musi zaufanie dla siebie czerpać nie tylko z mandatów rządu, ale i z kapitałów politycznych własnego kraju"39.

Treść depeszy przedstawił gen. K. Sosnkowski na posiedzeniu KSK w dniu 2 sierpnia 1940 roku. Powołując się na uzasadnienie w niej zawarte uznał, iż jest to rozwiązanie zgodne $\mathrm{z}$ instrukcjami i uchwałami rządu. Zamiast delegata rządu mianowano, w porozumieniu ze stronnictwami, czteroosobową delegaturę rządu. Biorąc pod uwagę trudności w łączności z krajem, zdaniem przewodniczącego KSK należało taką formę delegatury zbiorowej zalegalizować. Podobne stanowisko zajął J. Stańczyk, który uznał, że ,wobec braku dobrej łączności należy dać stronnictwom szerszy zakres uprawnień" ${ }^{, 40}$.

Zdecydowanie odmienne zdanie mieli w tej sprawie S. Kot, S. Mikołajczyk i K. Popiel, którzy rozpoczęli atak na ZWZ i jego politykę w kraju. Zakwestionowali także reprezentatywność Politycznego Komitetu Porozumiewawczego (PKP). S. Mikołajczyk podkreślił, iż nadal występują w kraju tendencje do podporządkowania stronnictw politycznych przez komendanta ZWZ, a ,w pewnych kołach wojskowych za pieniądze publiczne prowadzona jest robota nie tyle niepodległościowa, ile na rzecz dawnego reżimu" ${ }^{41}$. Zdaniem S. Mikołajczyka powołanie zbiorowej delegatury w kraju było sprzeczne z zasadami i instrukcjami przyjętymi przez rząd. Podkreślił (podobnie jak J. Stańczyk), że władzom polskim na uchodźstwie zależy na tym, aby nie ograniczać samodzielności stronnictw. Na zakończenie posiedzenia KSK podjęto uchwałę o utrzymaniu przyjętych zasad powoływania delegatów do czasu unormowania łączności z krajem.

W wyniku dyskusji, podjętej na forum komisji w dniu 12 października 1940 roku, rząd opracował instrukcję dla kraju, w której zażądał spełnienia zaleceń przekazanych tymczasowemu delegatowi. Przede wszystkim oczekiwano stworzenia porozumienia

\footnotetext{
${ }^{38}$ M. Dymarski, Stosunki wewnętrzne..., s. 126; W sprawie powołania Delegatury Zbiorowej zob. też: S. Korboński, Polskie..., s. 40-41.

${ }^{39}$ Archiwum Akt Nowych, Depesza gen. Roweckiego nr 34 z 14 VII 1940 r., sygn. 203/I-20, k. 7 .

40 Protokoty Posiedzeń Komitetu..., s. 307; Takie uprawnienia otrzymał dowódca ZWZ w depeszy od gen. Sosnkowskiego (podpisana przez premiera W. Sikorskiego) w dniu 18 czerwca 1940 r. Zgodnie z instrukcją gen. S. Rowecki mógł podejmować samodzielne decyzje w warunkach utraconej lub trwale utrudnionej łączności z władzami na uchodźstwie; zob.: Protokół z 23 posiedzenia Komitetu dla Spraw Kraju z dnia 2 sierpnia 1940 r., [w:] Protokoty Posiedzeń Komitetu..., s. 303-306.

41 Tamże, s. 309.
} 
czterech stronnictw (SL, PPS, SN, SP) orz wyłonienie wspólnego kandydata na delegata rządu. W instrukcji oczekiwano także, że stronnictwa będą między sobą uzgadniać wszelkie różnice zdań w sprawach ogólnych ,,a do rządu przez Delegata niech przekazują już uzgodnione postulaty”. Rząd zwrócił się do przywódców stronnictw z prośbą o

ponowne sprecyzowanie stanowiska, że decydować o potrzebach i sposobach działania rządu na kraj mają stronnictwa polityczne, a organizacja wojskowa jest tylko narzędziem rządu [...]. Rząd chce i musi mieć delegata swego, a nie delegaturę, co niesłusznie stworzono na skutek mylnej interpretacji wycofanej zresztą już dziś depeszy Sosnkowskiego $^{42}$.

W odpowiedzi na instrukcję rządu, Polityczny Komitet Porozumiewawczy (PKP) ${ }^{43}$ 27 października 1940 roku zobowiązał się, że najpóźniej do listopada wskaże kandydatów, a do czasu nowej nominacji funkcję delegata będzie pełnił „Vogel” (J. Skorobohaty-Jakubowski ${ }^{44}$. PKP dotrzymał obietnicy i 14 listopada przesłał do Londynu nazwiska kandydatów na delegata i jego zastępcę. O ile nazwisko zastępcy udało się rozszyfrować (był nim Cyryl Ratajski), o tyle nazwiska głównego delegata nie udało się ustalić. „Rząd uznał, że ma mimo wszystko kandydata uzgodnionego przez stronnictwa i ogłosił nominację [C. Ratajskiego]"45.

Sprawa delegata rządu była rozpatrywana na posiedzeniu KSK z udziałem A. Ciołkosza, który na skutek choroby J. Stańczyka został powołany 28 stycznia 1941 roku przez premiera Sikorskiego na zastępcę członka Komitetu ${ }^{46}$. 16 stycznia 1940 roku A. Ciołkosz skierował do przewodniczącego komitetu prośbę o zwołanie posiedzenia KSK celem omówienia spraw organizacji politycznych w kraju, ich finansowania oraz łączności z nimi ${ }^{47}$. W związku z tym, że jego projekt zawierał kwestie leżące jedynie

${ }^{42}$ AIPMS, sygn. A.9.II/2, k. 35.

${ }^{43}$ Polityczny Komitet Porozumiewawczy powstał 24 lutego 1940 r. w wyniku porozumienia przedstawicieli partii konspiracyjnych: PPS-WRN, SL, SN przy komendzie ZWZ. PKP miał za zadanie „zharmonizowanie przygotowań wojska i społeczeństwa do zbrojnego wystąpienia i osiągnięcia pełnego zwycięstwa nad okupantami”; S. Korboński, Polskie..., s. 33. Od kwietnia 1940 r. PKP został uznany przez władze RP na uchodźstwie za polityczną reprezentację kraju. Na przełomie lipca i sierpnia 1940 r. zdołał wzmocnić swoją pozycję jako Zbiorowa Delegatura Rządu RP na Kraj. Następnie został zreformowany do roli organu doradczego i opiniodawczego przy Delegacie Rządu RP na kraj. 15 sierpnia 1943 r., cztery partie PPS-WRN, SL, SN, SP podpisały „Deklarację porozumienia politycznego czterech stronnictw”, stanowiących Krajową Reprezentację Polityczną, a w październiku 1943 r. powołały Społeczny Komitet Antykomunistyczny, który na początku stycznia 1944 r. został przekształcony w Radę Jedności Narodowej; szerzej zob.: S. Korboński, Polskie..., A. Czubiński, Historia drugiej wojny światowej 1939-1945, Poznań 2004.

${ }^{44}$ Depesza PKP do gen. Sikorskiego z dnia 27 października 1940 r., [w:] Armia Krajowa $w$ dokumentach..., t. 1, s. 305; zob. też: AIPMS, kol. 25/12, Depesza 1a z 12 listopada 1940 r.

45 Okoliczności „niefortunnej nominacji Ratajskiego” wyjaśnia R. Buczek, Stronnictwo Ludowe 1939-1945, Londyn 1975, s. 192; zob. też: M. Dymarski, Stosunki wewnętrzne, s. 132. Według S. Korbońskiego premier Sikorski podjął decyzję o mianowaniu C. Ratajskiego, gdyż ten należał do Stronnictwa Pracy i w związku z tym gen. Sikorski mógł liczyć na pełną i bezkrytyczną lojalność. Winą za wybór C. Ratajskiego obciążył S. Korboński Stronnictwo Narodowe, które sprzeciwiało się pierwotnej kandydaturze SL i PPS (S. Korbońskiego jako Delegata głównego i J. Cyrankiewicza jako jego zastępcę); zob.: S. Korboński, Polskie..., s. 42. Według A. Ciołkosza kandydatem (PPS i SL) na delegata głównego miał być prof. J. Piekałkiewicz, a jego zastępcą A. Pajdak; zob.: A. Ciołkosz, Kartki z przeszłości..., s. 21.

${ }^{46}$ AIPMS, zespół Prezydium Rady Ministrów, sygn. 25, k. 73.

${ }^{47}$ Zakład Narodowy im. Ossolińskich, Papiery Sosnkowskiego z posiedzeń Rady Ministrów. Materiały związane z działalnością Rady Ministrów w latach 1940-1942, rps., sygn. 16523/II. 
w gestii ministra spraw wewnętrznych, gen. K. Sosnkowski zwrócił się do min. S. Kota z prośbą o ustalenie terminu posiedzenia Komitetu w porządku zaproponowanym przez A. Ciołkosza ${ }^{48}$. Gen. K. Sosnkowski otrzymał odpowiedź, iż , pewne sprawy muszą być poprzednio omówione ze stronnictwami politycznymi”. Niestety do przewodniczącego KSK nie dotarły żadne wyniki ustaleń i w związku z tym kwestie poruszone przez A. Ciołkosza nie mogły być omówione na posiedzeniu Komitetu ${ }^{49}$.

W istocie do zwołania KSK nie doszło ze względu na nieporozumienia i konflikt między gen. Sosnkowskim a premierem W. Sikorskim i min. S. Kotem ${ }^{50}$. Gen. K. Sosnkowski był nieustannie kontrolowany, a wszelkie przejawy samodzielności traktowano jako nielojalność wobec W. Sikorskiego.

Sporo kontrowersji i to zarówno w kraju, jak i za granicą budziła sprawa powołania delegata rządu oraz jego uprawnień ${ }^{51}$. Według A. Ciołkosza szczególnie zainteresowany sprawą delegata był min. S. Kot ${ }^{52} .2$ grudnia 1940 roku rząd zatwierdził nominacje dwóch głównych delegatów: C. Ratajskiego w Warszawie i A. Bnińskiego w Poznaniu. Zdaniem A. Ciołkosza wywołały one w kraju ,niezadowolenie i oburzenie, niemal wściekłość" ${ }^{53}$. Przeciwko C. Ratajskiemu wystąpiły SL i PPS, które w piśmie z 14 stycznia 1941 uznały, iż decyzja rządu odrzuca inicjatywę kraju w kwestii delegata, którym zgodnie z ustaleniami PPS, SL i SP miał być Jan Piekałkiewicz. W piśmie podkreślono, iż nominacja rządu nie odpowiada „rzeczywistemu układowi sił i nastrojów w kraju" (J. Piekałkiewicza) i zapowiedziano współpracę z PKP w zakresie spraw wojskowych i walki z okupantem ${ }^{54}$.

W tym czasie dokonały się zmiany w kierownictwie KSK, gdyż gen. K. Sosnkowski uznał, że przewodniczyć Komitetowi powinien min. S. Kot, gdyż byłoby to połączenie jego kompetencji (ministra spraw wewnętrznych) ze stanem faktycznym. Na początku stycznia 1941 roku gen. K. Sosnkowski podał się do dymisji, a premier Sikorski mianował Kota na przewodniczącego KSK.

24 posiedzenie Komitetu odbyło się 7 stycznia 1941 roku po raz pierwszy pod przewodnictwem S. Kota, który podziękował swojemu poprzednikowi za wkład, jaki włożył w tworzenie KSK i kierowanie jego pracami. S. Kot poinformował zebranych o sytuacji w kraju, gdzie nasilił się terror niemiecki.

Według pierwotnych zamierzeń S. Kota obrady Komitetu miały dotyczyć w głównej mierze uprawnień delegata. Przeszkodził temu jednak A. Ciołkosz, który zwrócił uwagę na bardzo małą częstotliwość zebrań KSK i podkreślił, że nie były one zwoływane przez pięć miesięcy. Poprosił o wyjaśnienie przyczyn tak długiej przerwy w ob-

${ }^{48}$ Pismo gen. K. Sosnkowskiego z dnia 14 grudnia 1940 r. do ministra Kota w sprawie zwołania posiedzenia KSK i ustalenie porządku dziennego, [w:] Protokoty Posiedzeń Komitetu..., s. 427.

49 Tamże, s. 396.

${ }^{50} \mathrm{Na}$ temat konfliktu premiera Sikorskiego z gen. Sosnkowskim zob.: E. Duraczyński, Kontrowersje..., s. 288-298.

${ }^{51}$ Szerzej zob.: W. Grabowski, Delegatura Rzadu Rzeczypospolitej Polskiej na Kraj 19401945, Warszawa 1995; J. Paśnik, Status prawny Delegata Rządu na Kraj 1940-1945, Toruń 1991.

${ }_{52}$ A. Ciołkosz, Kartki z przeszłości..., s. 17.

${ }^{53}$ Tamże.

${ }^{54}$ Armia Krajowa w dokumentach..., t. 1, s. 404-405; A. Ciołkosz, Kartki z przeszłości..., s. 18; zob. też: AIPMS, zespół PRM, 46a, Sprawozdanie Delegata Rządu „Warskiego” za okres do 10 I 1941 r. Stanowiska SL i PPS-WRN w Kraju nie podzielali ludowcy w rządzie W. Sikorskiego: S. Mikołajczyk i S. Kot oraz przedstawiciel socjalistów - H. Lieberman, co zdaniem E. Duraczyńskiego „skutecznie paraliżowało możliwości powstania jednolitego bloku socjalistyczno-ludowego obejmującego kraj i emigrację"; E. Duraczyński, Kontrowersje..., s. 281. 
radach Komitetu. Gen. K. Sosnkowski wyjaśnił, iż nikt z osób uprawnionych do tego (premier, ministrowie, członkowie KSK) nie widział potrzeby zwołania obrad Komitetu. Pierwszą osobą, która podjęła taką inicjatywę był A. Ciołkosz. Poza tym gen. K. Sosnkowski zaznaczył, iż posiedzenia KSK nie były zwoływane ze względu na jego „niewłaściwą konstrukcję” i nałożenie się uprawnień. „Początkowo w jego rękach skupiała się całość pracy w Kraju, a więc działalność wojskowa i polityczna"55. Dopiero nieco później nastąpił rozdział tychże obowiązków. Generał K. Sosnkowski uważał, że Komitet zajmując się w głównej mierze sprawami natury ogólnej bądź politycznej łączności z krajem powinien podlegać ministrowi spraw wewnętrznych. Z tego względu kierownictwo Komitetem powinno być powierzone ministrowi S. Kotowi.

W dalszej części wystąpienia A. Ciołkosz podjął kwestię informowania członków KSK oraz sposobu, w jaki przesyłane są wiadomości do kraju. Poruszył również sprawę funduszy przekazywanych na działalność stronnictw konspiracyjnych. Podkreślił jednocześnie, iż PPS-WRN nie otrzymała żadnych pieniędzy ${ }^{56}$. Odpowiadając na pytania A. Ciołkosza w sprawie informowania kraju o pracach Komitetu, min. S. Kot stwierdził, że „nie wie czy zgodziłaby się na to Rada Ministrów oraz premier. Nie ulega

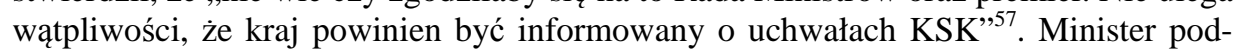
kreślił jednocześnie, że w kraju pojawiają się ludzie, którzy twierdzą, iż mają instrukcje od stronnictw z zagranicy. Sam minister wysyła kurierów jedynie do kierownictwa stronnictw. W sprawie pieniędzy przekazywanych poszczególnym stronnictwom w kraju S. Kot poinformował, że dotychczas nie udało mu się „dostać wyczerpujących wyjaśnień z Polski, jakie sumy pieniężne dotarły i jak zostały rozdzielone" ${ }^{\natural 8}$. W warunkach konspiracji kontrola nad przepływem funduszy jest bardzo utrudniona. Minister S. Kot podkreślił, że pieniądze dla PPS dotarły do przedstawiciela partii w Krakowie. Nadal jednak nie otrzymał żadnych informacji dotyczących szczegółów rozdziału funduszy oraz wskazania osób, do których powinny one trafić.

A. Ciołkosz doprecyzował swoje pytanie, dotyczące funduszy na działalność stronnictw w kraju, i podkreślił, iż nie chodzi mu o to ,pod czyim adresem zostały one wysłane, ale dla kogo były przeznaczone" ${ }^{, 59}$. A. Ciołkoszowi chodziło przede wszystkim o szczegółowe sprawozdanie finansowe z przesłanych do kraju pieniędzy. Wniosek ten poparł S. Mikołajczyk i K. Popiel. Akceptację części zebranych uzyskała również inicjatywa regularnego (raz w miesiącu) zwoływania posiedzeń KSK.

Nawiązując do pierwszego punktu obrad, dotyczącego uprawnień delegata rządu ${ }^{60}$, przewodniczący Komitetu przypomniał, że na skutek braku porozumienia między stronnictwami w kraju powołana została delegatura zbiorowa, co było niezgodne z koncepcją rządu. Bez podawania nazwisk S. Kot stwierdził, iż „ludzie stronnictw sugerowali rządowi, aby nie czekał na personalne propozycje, bo stronnictwa nie są zdolne jednolicie uzgodnić kandydatów, oraz by rząd sam dokonał wyboru osoby odpowied-

${ }^{55}$ Protokoty Posiedzeń Komitetu..., s. 394.

${ }^{56}$ Tamże.

57 Tamże, s. 395.

58 Tamże.

${ }^{59}$ Tamże.

${ }^{60}$ Pogląd na temat delegata rządu S. Kot wyraził w listopadzie 1940 r. w memoriale, który przedstawił uzasadnienie dla szczególnych uprawnień delegata. Powinien on, zdaniem S. Kota, zapobiegać wpływom politycznym ZWZ, w którym ogromna rolę odgrywała sanacja; E. Duraczyński, Kontrowersje..., s. 304. 
niej, niemającej zbyt jaskrawego piętna partyjnego" ${ }^{\text {"61 }}$. Po otrzymaniu z kraju nazwiska wspólnie uzgodnionego przez trzy stronnictwa kandydata, który został przez premiera uznany za kandydaturę „,odpowiednią i niedrażniącą”, wysłał do kraju nominację na Delegata Rządu na Kraj - C. Ratajskiego ${ }^{62}$.

Podczas dyskusji nad uprawnieniami delegata głos zabrał A. Ciołkosz, który przedstawił tezę, że „centrala życia politycznego znajduje się w Kraju, a Rząd jest filią polityki krajowej. Musi to być wzajemna umowa, że rząd jest Krajowi podległy"63. Odniósł się także do sprawy kontroli przez delegata rządu niektórych działań komendanta ZWZ. Uważał, że delegat powinien zakresem swych kompetencji obejmować cały kraj (identycznie jak obszar działania komendanta ZWZ) ${ }^{64}$. Był to ważny argument przemawiający za powołaniem tylko jednego delegata rządu. $Z$ poglądami A. Ciołkosza nie zgodził się prof. Folkierski i S. Mikołajczyk ${ }^{65}$.

Eskalację napięć wywołała depesza z dnia 13 stycznia 1941 roku gen. W. Sikorskiego do C. Ratajskiego. Według A. Ciołkosza zmieniała ona w zasadniczy sposób dotychczasowe ustalenia dotyczące delegata rządu. Po zapoznaniu się z treścią depeszy kierownictwo PPS-WRN uznało ją za ,proklamację wojny Rządu emigracyjnego z krajowymi organizacjami chłopów i robotników"66. Władze PPS-WRN opracowały uwagi do depeszy, które w sposób krytyczny odnosiły się do jej treści. Zarówno według socjalistów, jak i ludowców uległa zmianie koncepcja rządu w sprawie Delegatury, która miała stanowić jedynie „,iurokratyczny czynnik rządzenia krajem bez uwzględniania opinii czterech stronnictw" ${ }^{, 67}$. Taka sytuacja pozbawiała Delegaturę kontroli społecznej nawet w sprawach finansowych. W toku rozmów miedzy SL a PPS ustalono, że

podział kraju na trzy delegatury był błędem Rządu, a powołanie C. Ratajskiego na delegata będzie funkcją jedynie reprezentatywną: oba stronnictwa zapowiedziały utrzymanie kontaktu z delegatem tylko w sprawach wojskowych i walki z okupantem ${ }^{68}$.

${ }^{61}$ Protokoty Posiedzeń Komitetu..., s. 397.

${ }^{62}$ Nominacja C. Ratajskiego budziła wiele kontrowersji w kraju. „Jego cechy osobiste zdaniem Z. Zaremby — również czynią go niezdolnym do tej funkcji i na pewno wywołają szereg kompromitacji”; cyt. za: A. Ciołkosz, Kartki z przeszłości, s. 18.

${ }^{63}$ Protokoty Posiedzeń Komitetu..., s. 398-399.

${ }^{64}$ Wniosek A. Ciołkosza w tej sprawie nie doczekał się uchwały zatwierdzającej. Ciołkosza poparł jedynie gen. Sosnkowski. S. Mikołajczyk oraz S. Kot powoływali się na depeszę Sikorskiego do Ratajskiego z 13 stycznia 1941 r., w której premier zaznaczył, by delegat warszawski „W razie potrzeby decydował w sprawach całego terytorium Polski”; cyt. za: E. Duraczyński, Kontrowersje..., s. 311.

${ }^{65}$ Szerzej zob.: Protokoty Posiedzeń Komitetu..., s. 399; S. Kot wraz z K. Popielem i S. Mikołajczykiem przygotowywali kolejny projekt zasad regulujących stosunki między delegatem a komendantem ZWZ. Swoją propozycję S. Kot przedstawił premierowi; zob.: AIPMS, zespół PRM, 47, List Sikorskiego do Sosnkowskiego z 11 stycznia 1941.

${ }^{66}$ W sprawie depeszy odniósł się w liście do A. Ciołkosza z 22 stycznia 1940 r. Z. Zaremba, który podkreślił, że „,nie zależy nam na wojnie z Rządem i chcemy jej uniknąć, ale nie możemy dopuścić do polityki, która w efekcie musi dać biurokratyczne zagmatwanie stosunków, szerokie pole do intryg kanapowych grup i odskocznię dla faszystowskich planów endeckich"; zob.: A. Ciołkosz, Kartki..., s. 18.

${ }^{67}$ Tamże, s. 18-19; zob. też: AIPMS, zespół PRM 46 A/9, Deklaracja PPR-WRN („Koło”) i SL (,Trójkąt”) do Rządu Rzeczypospolitej Polskiej i Rady Narodowej w związku z mianowaniem Cyryla Ratajskiego PS. „Warski”, Delegatem Rządu na Kraj.

${ }^{68}$ A. Ciołkosz, Kartki..., s. 20; Ostatnie pismo uzasadniające koncepcję jednego delegata rządu wysłał K. Pużak do premiera Sikorskiego. Argumentował on, że centralna delegatura rządu, któremu 
Kontrowersje wokół osoby Delegata Rządu na Kraj stały się prawdopodobnie przyczyną tego, że w ciągu 1941 roku przewodniczący S. Kot zwołał posiedzenie komitetu jedynie trzy razy (19 i 21 lutego oraz 13 marca).

Podczas 25 posiedzenia KSK w dniu 19 lutego 1941 roku A. Ciołkosz zadał pytanie dotyczące ilości delegatów (jednego czy trzech?). Powołując się na uchwałę z dnia 17 kwietnia 1940 roku, która przewidywała jednego delegata, A. Ciołkosz złożył wniosek o ustanowienie jednego delegata centralnego na obszar całej Polski ${ }^{69}$. Zabrał także głos w sprawie uprawnień delegata rządu. Poparł wniosek K. Popiela, aby „rozszerzyć kompetencje delegata rządu przez nadanie mu prawa kontroli działalności ZWZ noszącej charakter polityczny z wyłączeniem czynności techniczno-wojskowych organizacji”, ${ }^{70}$.

A. Ciołkosz opowiadał się za jak najszybszym uporządkowaniem ,odcinka cywilnego, a następnie wojskowego". Uważał ponadto, iż zadanie unormowania stosunków między stronnictwami a ZWZ należy powierzyć delegatowi ${ }^{71}$. Jednocześnie położył nacisk na konieczność współpracy między czynnikami politycznymi i wojskowymi, gdyż „mimo niezbędnego apolitycznego charakteru pracy ZWZ, przygotowanie ideologiczne szeregów na okres walki jest potrzebne"72. Uważał, iż centrum myśli politycznej znajduje się w kraju i tam tworzą się koncepcje i wizje przyszłej Polski.

Od początku działalności emigracyjnej A. Ciołkosz stał na stanowisku, iż kierownictwo życia politycznego jest w Polsce i z momentem zakończenia wojny o losach Polski decydować będą czynniki w kraju ${ }^{73}$. W konkluzji swojego wystąpienia na forum KSK podkreślił, iż do realizacji nowej idei potrzebna jest konsolidacja stronnictw w kraju, ale też spójność działania między nimi a władzami emigracyjnymi ${ }^{74}$.

Podczas kolejnego posiedzenia Komitetu w dniu 21 lutego 1941 roku głos zabrał S. Mikołajczyk, który zaatakował szereg tez A. Ciołkosza i K. Sosnkowskiego, a w szczególności tezę o filialnej roli rządu. Stwierdził, iż niesłuszna jest opinia jakoby

Rząd w Londynie był jedynie wielką ambasadą Kraju za granicą reprezentującą tylko to, co w danym momencie jest korzystne dla Państwa. Rząd Jedności Narodowej jest pełnoprawnym rządem w każdej dziedzinie. Gdyby było inaczej, jego prawo reprezentowania interesów Polski nie miałoby dostatecznie silnych podstaw. Zgodnie z interesem Państwa zarówno w dziedzinie walki, przedstawicielstwa na zewnątrz, przygoto-

powinny podlegać $\mathrm{w}$ miarę potrzeby delegaci poszczególnych okupacji i terytoriów ,,[...] winien sprawować swe funkcje w ścisłym porozumieniu i w lojalnej współpracy stronnictw na zasadach primus inter pares. Stronnictwa ze swej strony, niosąc wspólnie z delegatem odpowiedzialność, powinny pełnić rolę nie tylko doradczą, ale też kontrolująca czynności delegata”. W dalszej części lider socjalistów stwierdził, że delegatem i jego zastępcą powinni być reprezentanci robotników i chłopów. Delegatem powinna być osoba wskazana przez SL, a zastępcą wskazana przez PPS.

${ }^{69}$ Protokoty Posiedzeń Komitetu..., s. 555.

${ }^{70}$ Tamże, s. 554. Najwięcej zastrzeżeń do prowadzenia działań politycznych niektórych sanacyjnych dowódców ZWZ miał S. Mikołajczyk i S. Kot. Uważali oni, iż oficerowie ZWZ tworzą konspiracyjną władzę polityczną i w związku z tym dążyli do podjęcia uchwały ograniczającej prowadzenie jakiejkolwiek działalności politycznej przez ZWZ i poddanie go kontroli władz cywilnych (delegata rządu).

${ }^{71}$ Tamże.

72 Tamże, s. 555.

73 Tamże, s. 587. Podzielał w tym względzie stanowisko K. Pużaka.

${ }^{74}$ Podobne stanowisko zajął sekretarz generalny PPS-WRN K. Pużak w liście do premiera W. Sikorskiego z 3 marca 1941 r.; szerzej zob.: Armia Krajowa $w$ dokumentach 1939-1945, t. 6: Uzupetnienia, [kom. red. H. Czarnocka i in.], Londyn 1989, s. 175-176; AIPMS, zespół PRM 45.c/9. 
wań do ostatecznej rozgrywki powietrznej [tak w oryginale — L.B.P.] oraz planu odbudowy $^{75}$.

W dalszej części wystąpienia S. Mikołajczyk zaprzeczył, jakoby zniknęło niebezpieczeństwo sanacyjne. Odrzucił także postulat gen. K. Sosnkowskiego dotyczący „równego startu” w pracy niepodległościowej dla wszystkich nieskompromitowanych piłsudczyków" ${ }^{\text {76. }}$.

W odpowiedzi na zarzuty S. Mikołajczyka A. Ciołkosz ponownie przedstawił koncepcję dotyczącą kierowniczej roli konspiracyjnych władz w kraju oraz konieczności utrzymania ich łączności z rządem na uchodźstwie. Dlatego tak ważne, jego zdaniem, było porozumienie stronnictw politycznych. Główną przeszkodą w ich konsolidacji były działania endecji, a „siły społeczne, które kryją się za endecją, zmierzają po prostu do zajęcia miejsca sanacji" "77. Aby temu zapobiec należy dążyć do zjednoczenia sił demokratycznych, które reprezentują większość społeczeństwa polskiego (chłopi, robotnicy i pracownicy umysłowi). A. Ciołkosz przypomniał członkom KSK, że idea ta została zapoczątkowana przez Tymczasowy Rząd Ludowy Rzeczpospolitej Polskiej, który powstał 7 listopada 1918 roku w Lublinie na czele z Ignacym Daszyńskim ${ }^{78}$.

Efektem końcowym debaty Komitetu z lutego 1940 roku było podjęcie uchwały w dniu 10 kwietnia w sprawie uprawnień delegata rządu ${ }^{79}$. Po jej ogłoszeniu nastąpiła roczna przerwa w obradach Komitetu (kwiecień 1941 - marzec 1942), która była spowodowana rozbieżnościami dotyczącymi delegata rządu oraz kontrowersjami związanymi z układem Sikorski-Majski. Wobec bierności KSK i braku podejmowania jakichkolwiek działań znaczenie Komitetu znacznie spadło ${ }^{80}$. Dopiero pod naciskiem socjalistów wznowił on swoje prace w lutym 1942 roku. Nowym jego przewodniczącym został S. Mikołajczyk. W nowym składzie Komitetu znaleźli się: W. Banaczyk, K. Popiel, A. Ciołkosz i W. Komarnicki ${ }^{81}$.

14 czerwca 1942 roku A. Ciołkosza zastąpił w KSK przybyły ze ZSRR Jan Kwapiński (powołany 5 czerwca na Ministra Przemysłu i Handlu). Odwołanie A. Ciołkosza nastąpiło bez podania przyczyn, ale zapewne niemały wpływ na to miała jego zdecydowanie opozycyjna postawa wobec rządu W. Sikorskiego, która nasiliła się po zawarciu układu polsko-sowieckiego ${ }^{82}$.

Usprawnienie prac KSK nastąpiło po uchwaleniu przez Radę Ministrów w dniu 11 września 1942 roku regulaminu działalności Komitetu ${ }^{83}$. Zaangażowany był on

${ }^{75}$ Protokoty Posiedzeń Komitetu..., s. 583. Według E. Duraczyńskiego „była to mocna argumentacja i nic dziwnego, że Ciołkosz nie mógł jej niczego sensownego przeciwstawić”; E. Duraczyński, Kontrowersje..., s. 308.

${ }^{76}$ Szerzej zob. wystąpienie S. Mikołajczyka (Protokoty Posiedzeń Komitetu..., s. 583-587).

77 Tamże, s. 587.

${ }^{78}$ Tamże.

${ }^{79}$ Armia Krajowa w dokumentach..., t. 1, s. 508. Uchwała z 10 kwietnia 1941 r. stanowiła uzupełnienie do uchwały z 16 kwietnia 1940 r. (, Zasady organizacyjne pracy w Kraju”).

${ }^{80}$ M. Dymarski, Stosunki wewnętrzne..., s. 133.

${ }^{81}$ Protokoty Posiedzeń Komitetu..., s. 28; AIMPS, kol.133/387, Pismo Prezesa Rady Ministrów do A. Ciołkosza z 3 lutego 1942.

82 „My tu żyjemy jak w obozie warownym”. Listy PPS-WRN Warszawa-Londyn 1940-1945, Londyn 1992, s. 147.

${ }^{83}$ Projekt regulaminu KSK opracowany przez ministra spraw wewnętrznych S. Mikołajczyka został przedstawiony na posiedzeniu komitetu w dniu 10 sierpnia 1942 r.; szerzej zob.: AIPMS, zespół PRM L.22, poz. 1, Regulamin KSK. 
w prace nad kolejnymi instrukcjami dla kraju oraz analizę bieżącej działalność w kraju. Po śmierci gen. W. Sikorskiego (4 lipca 1943 roku) i zmianach w rządzie (premierem został S. Mikołajczyk), 18 sierpnia powołano nowy skład KSK z przewodniczącym, który pełnił jednocześnie funkcję Prezesa Rady Ministrów.

W kolejnych miesiącach swojej pracy Komitet wyrażał m.in. opinie na temat sądownictwa doraźnego czy dekretu Prezydenta RP o ochotniczej służbie kobiet. Aktywnie pracował nad projektem dekretu o tymczasowej organizacji władz na terytorium Rzeczypospolitej. Jego ostateczny tekst został podpisany 26 kwietnia 1944 roku $^{84}$. W maju 1944 roku KSK uchwalił projekt utworzenia delegata rządu dla spraw wychodźstwa polskiego we Francji, Belgii i Holandii. W kolejnych miesiącach Komitet zajmował się rozpatrywaniem wiadomości napływających z Polski. Opracował kolejne wersje instrukcji dla Kraju, przedkładając je rządowi do uchwalenia.

Do ponownych zmian w składzie KSK doszło w listopadzie 1944 roku, kiedy to, po dramatycznych walkach w stolicy i klęsce powstania warszawskiego oraz informacjach, jakie otrzymał premier od W. Mołotowa o ustaleniach konferencji teherańskiej, 24 listopada S. Mikołajczyk podał się do dymisji. 29 listopada został sformułowany rząd T. Arciszewskiego. 5 grudnia powołał on Komitet Spraw Krajowych na czele z Prezesem Rady Ministrów. Zdecydowano również, że przy rozpatrywaniu spraw wojskowych mają być obecni: szef Sztabu Wodza (gen. Stanisław Kopański) oraz gen. Stanisław Tatar ${ }^{85}$. W ciągu dwóch tygodni został zmieniony również regulamin KSK, który umożliwiał udział w posiedzeniach Komitetu przedstawicieli stronnictw politycznych ${ }^{86}$. Zmiany te były rezultatem oczekiwań politycznych środowisk emigracyjnych, które wnosiły zastrzeżenia do działalności rządu S. Mikołajczyka i KSK pod jego kierownictwem.

Rząd T. Arciszewskiego, oparty głównie na PPS, SN i SP (SL pozostało w opozycji), nie dysponował wystarczającą siłą, która mogłaby zmienić niekorzystne położenie Polski. Uchwały jałtańskie oraz sytuacja na ziemiach polskich spowodowały, że rząd emigracyjny został pozbawiony łączności z krajem. Nie był w stanie wpływać na sytuację międzynarodową i wewnętrzną Polski. Kiedy 28 czerwca 1945 roku utworzono z inicjatywy ZSRR Tymczasowy Rząd Jedności Narodowej (z udziałem S. Mikołajczyka) powstała dwuwładza, choć de iure nadal jedyną legalną władzą RP pozostawał rząd na uchodźstwie. TRJN został jednak uznany przez USA, Wielką Brytanię, Francję i ZSRR.

Mimo cofnięcia uznania legalnemu rządowi polskiemu na uchodźstwie (5 lipca 1945 roku) przez zachodnich sojuszników nie przyjął on decyzji jałtańskich i nadal kontynuował swoją działalność, aż do odzyskania przez Polskę pełnej suwerenności. W działania władz emigracyjnych zaangażowany był również A. Ciołkosz, który przez cały okres II wojny światowej pozostawał wierny socjalistycznym ideałom i przestrzegał ściśle zasad współpracy między władzami stronnictwa w okupowanym kraju, a Komitetem Zagranicznym PPS. Był lojalny wobec ustaleń władz PPS-WRN, które uważał za nadrzędne w stosunku do władz emigracyjnych partii.

Po zakończeniu wojny pozostał na emigracji w Londynie, kierując z małymi przerwami pracami PPS w Wielkiej Brytanii. Od 1949 roku wchodził również w skład Wydziału Wykonawczego Rady Politycznej grupującej demokratyczne organizacje na emigracji. A. Ciołkosz należał do najbardziej zagorzałych przeciwników układu jałtań-

\footnotetext{
${ }^{84}$ Szerzej zob.: W. Grabowski, Delegatura Rzadu Rzeczypospolitej Polskiej...

${ }^{85}$ Protokoty Posiedzeń Rady Ministrów..., s. 9.

${ }^{86}$ Tamże, s. 51, 57-58.
} 
skiego i ostro sprzeciwiał się sowietyzacji nie tylko Polski, ale także innych państw, które znalazły się po wojnie w strefie wpływów sowieckich. Należał do zwolenników socjalizmu demokratycznego i obnażał wszelkie ideologiczne kłamstwa komunistów i tzw. „socjalistów krajowych”.

Od 1954 roku wchodził (jako wiceprzewodniczący) w skład Egzekutywy Zjednoczenia Narodowego (EZN) będącego alternatywnym rządem emigracyjnym. W latach 1956-1959 oraz 1963-1966 pełnił funkcję przewodniczącego EZN ${ }^{87}$. Przez cały okres powojennej działalności uprawiał pisarstwo polityczne i historyczne, publikując kilka książek i setki artykułów w prasie wielu krajów.

Ciołkosz zmarł w Londynie 1 października 1978 roku.

${ }^{87}$ Szerzej zob.: F. Gross, Wspomnienie o Adamie Ciotkoszu, [w:] Ludzie PPS, Londyn 1967; Adam Ciotkosz. Polityk — pisarz — historyk socjalizmu, Londyn 1972. 
